\title{
POLICY RESPONSIVENESS AND POLITICAL ACCOUNTABILITY IN CITY POLITICS
}

\author{
Anthony Sayers and Jack Lucas
}

\section{SUMMARY}

Peculiar patterns have emerged in municipal politics in Canada. Unlike at federal and provincial levels of government, party politics is weak or absent in cities. But looking at the entire history of municipal elections of three Western Canadian cities - Calgary, Edmonton and Vancouver - also finds that, again unlike politicians at higher levels, municipal representatives are increasingly more likely to win repeated re-elections, facing a much lower threat from any competitive challenge. In addition, the careers of municipal politicians are growing steadily longer, leading to relatively stable, almost static, city governments that tend to see change most commonly when councillors choose to step down, rather than being forced out.

Such patterns, of course, run counter to the general presumption in lively democracies, including this one, that the responsiveness of government leaders (that is, following the wishes of their constituents) and their accountability for the actions they take are best served by frequent turnovers in government: The need to throw politicians out every now and again to let new ones try and do things better. Whether the remarkable levels of stability and incumbency on city councils actually do serve the best interests of voters is unclear. More clear is that the lack of a party system at the city level seems to have contributed to this peculiar dynamic, and that city politicians have an interest in keeping it that way.

While party affiliations provide a candidate some benefits in the form of campaign co-ordination, they also provide voters with increased clarity about what each candidate stands for policy-wise. That might be helpful to voters, but city politicians might find it more useful to blur their positions, leaving voters uncertain of exactly how to define a specific councillor's stand, overall. The

Our thanks to Adrian Raddatz for excellent research assistance and to Carol Stokes of the City of Calgary archives for providing us with archival materials on Calgary's city council. We also gratefully acknowledge the financial support of the University of Calgary School of Public Policy. Portions of this paper are taken from "Accountability, Responsiveness, and the Local Political Career in Calgary and Edmonton," to be included in Accountability and Responsiveness at the Municipal Level, View from Canada, ed. Sandra Breux and Jérôme Couture. 
amount of information required to root through a councillor's voting record, and the relatively light media coverage of daily council business, leaves most voters inclined to rely on something other than political signals when they decide who to support. Inevitably, a candidate's personal character and length of experience take on a larger priority in the voting decision. So, the longer a councillor serves, the longer he or she might be likely to keep serving.

The natural outcome of this phenomenon is that city councils are less likely to become polarized as councillors have an incentive to seek consensus by limiting obvious policy distinctions between themselves and their fellow representatives, contributing to a dynamic where city council works more like a corporate body and less like a partisan legislature. As long as citizens remain largely unperturbed by the overall actions of their city council, they might judge the risk of replacing them at election time as unnecessarily high compared to sticking with the status quo.

This behaviour challenges much of the prevailing theory about how political processes improve political responsiveness and accountability. This is occurring at a time when cities are emerging as important and increasingly powerful nodes in the modern global economy. That the very nature of how they are governed is diverging so markedly from the norm that Canadians have come to expect from other levels of government is not something to be considered lightly. 


\section{INTRODUCTION}

Responsiveness and accountability are central to our understanding of the policy process in representative democracies. Governments are responsive to the preferences of voters, who in turn hold governments to account for their policies and actions. Elections are the central means for achieving these ends. By studying elections in Calgary, Edmonton and Vancouver, we seek to understand how these mechanisms operate in the city politics that increasingly shape the policy environment experienced by most Canadians.

Elections are an opportunity for voters to cast a ballot that reflects their policy preferences as well as an assessment of the past performance of governments and politicians. A voter selects the choice that best matches his or her prospective policy preferences and a retrospective assessment of whether his or her situation has improved or worsened over the time the government has been in office. This provides incentives for politicians to take account of the wishes of voters and in general behave well, and for voters to build policy preferences and remain informed as to the actions of elected officials.

We are particularly interested in whether the signalling required to sustain these relationships is present at municipal elections, which regularly exhibit low levels of competition and provide voters with limited information on the position of candidates and the actions of council. That is, do the peculiar circumstances of municipal elections alter the behaviour of voters and politicians compared to that found in federal and provincial elections?

Our unique dataset allows us to consider such questions via the careers of 910 councillors and mayors in three Canadian cities, Calgary, Edmonton and Vancouver, across all elections since their incorporation. That is, since 1885, 1892 and 1886 respectively. Linking these data to the Canadian Elections Database allows us to identify those who also had careers at the provincial and national levels. ${ }^{1}$ With this information, we analyze various features of the political careers of municipal politicians for insight into the nature of responsiveness and accountability in city politics and beyond.

We operationalize responsiveness and accountability as clarity of choice and concentration of responsibility respectively. ${ }^{2}$ We consider how career duration, rates of incumbency, turnover in council membership, and the trajectory of municipal political careers shape voters' ability to correctly identify the candidate who best reflects her or his policy preference and to identify those responsible for past policy decisions that have shaped voters' circumstances. ${ }^{3}$ Each of these features has implications for the burden on voters seeking to understand the policy positions of candidates for election - clarity of choice - and the decisions made by past councils - concentration of responsibility - in what is usually a low-information environment.

We find that long career duration, low turnover, high rates of incumbency, and political trajectories beyond city council enhance clarity of choice and concentration

Anthony M. Sayers, Canadian Elections Database, http://canadianelectionsdatabase.ca/PHASE4/, accessed February 7, 2017.

Russell J. Dalton and Christopher Anderson, Citizens, Context, and Choice: How Context Shapes Citizens' Electoral Choices (New York: Oxford University Press, 2011).

Accountability has been operationalized in many ways in the political-science and public-policy literatures to capture different aspects of answerability, including those with little direct connection to elections (such as input and output legitimacy in the policy process). Our focus in this paper is on politicians and political careers, and thus on political accountability and elections. 
of responsibility by increasing the likelihood that voters know the policy positions of candidates and the past decisions of councillors. That is, all things being equal, stability enhances voter knowledge of the policy positions of some of those seeking election and the actions of past councils. Given that stability may also shape levels of voter engagement in elections, a full understanding of these effects is not possible given the data that are currently available for our three cases.

Stability as a representational advantage runs counter to the presumption that regular turnover in a legislative body is prima facie evidence of responsiveness and accountability. To explore this further, we consider the sources of inertia in civic politics and the lack or at least underdevelopment of political parties in our case studies.

In a low information environment, incumbents have a great deal of freedom to shape public perceptions of their policy preferences and record on council with an eye to gaining reelection. This may well limit the appeal of partisan politics. Incumbents may well judge the electoral and legislative coordination advantages that come with the development of disciplined political parties as outweighed by the added transparency and limitations on their strategic behaviour that these imply.

In addition, without a dominant executive, councils lack the centralizing dynamics that help to sustain disciplined political parties. ${ }^{4}$ Limited or no partisan competition in turn denies the media access to the gladiatorial forms of political reporting that has helped strengthen the role of parties elsewhere.

Politicians face incentives to operate as a collective with their fellow councillors, minimizing predictable differences on policy and avoiding scandal that might lead moderately informed voters to defeat them as a group. This suggests that those wishing to influence councils should fashion strategies that are consistent with councillors' sense of corporate unity and the lack of executive control of the legislative agenda.

As for voters, with little evidence that stability leads to regular crises on council, and only a general impression of the policy positions of incumbents, it may be rational for them to either re-endorse city politicians based on experience, or to not vote at all. This is particularly so if it is not in the interests of councillors to highlight policy differences nor poor performance by other council members

Responsiveness and accountability appear to operate in unique ways at city elections. Limited competition in a low information environment alters the behaviour of politicians and voters from that found at other elections. The paucity of research on civic politics does not allow us to fully explore these ideas, but they are deserving of closer attention.

\section{CITIES}

Cities are increasingly important in the lives of people and the global economy. In 1950, 30 per cent of the global human population lived in cities and 70 per cent in the countryside; by 2050 these numbers will be reversed, with 70 per cent of people living in cities and a minority in the countryside. Cities encompass a growing share of the global economy as

\footnotetext{
Gary W. Cox, The Efficient Secret: The Cabinet and the Development of Political Parties in Victorian England (Cambridge: Cambridge University Press, 1987).
} 
service and knowledge industries join traditional manufacturing to contribute to their role as attractors of the highly educated, entrepreneurial, high-net-worth individuals who drive economic growth. ${ }^{5}$

While modern cities are not usually sovereign, limitations on the power of nation states combined with the vitality of cities is reshaping the relationship between the two. The growing importance of cities in national and international economic and political affairs and their role as service delivery mechanisms suggest the binary distinction — state versus non-state city - may be of less value in describing how political and economic power operate in a globalized world. ${ }^{6}$ They are critical nodes in the international economy and central to successfully dealing with the modern challenges and opportunities relating to transportation, technology, energy, and the environment.

Currently, the city of London is exploring special arrangements with respect to immigration and workforce management as a means of avoiding challenges to its prosperity that might flow from Britain exiting the European Union. ${ }^{7}$ Among the powers that the mayors of Edmonton and Calgary have floated for possible inclusion in a proposed city charter are administrative tribunals to deal with bylaw offences, greater local control of planning for publicly financed infrastructure such as schools, and new taxing powers. ${ }^{8}$

Canadian cities collectively raise, spend, and borrow billions of dollars, provide extensive goods and services to the public, and oversee major infrastructure investments. ${ }^{9}$ They regularly bid for or host major international events, such as the Olympics, that bind provincial and federal governments to massive outlays. They also play a key role in provincial and national politics and in the formation of central decision-making institutions such as federal and provincial cabinets. ${ }^{10}$ To understand the politics and policy-making of cities is to understand the politics and policy-making of the future.

\section{CLARITY OF CHOICE AND CONCENTRATION OF RESPONSIBILITY}

To be fully engaged, democratic responsiveness and accountability require clarity of choice and concentration of responsibility. Elections must offer clear and comprehensible choices among parties, leaders and candidates if voters are to signal their policy preferences to governments effectively. For governments to be retrospectively punished or rewarded for

See, for example, Joseph Parilla and Alan Berube, "Metro North America: Cities and the Metros as Hubs of Advanced Industries and Integrated Goods Trade" (Brookings Institution, 2013), https:/www.brookings.edu/wp-content/ uploads/2013/11/bmpp_MetroNA_FINAL.pdf.

6 Warren Magnusson, The Politics of Urbanism: Seeing Like a City (London: Routledge, 2011).

7 Marc Champion, "What will become of London after Brexit?" Bloomberg, October 21, 2016.

8 Nenshi, Naheed. 2016. 'Nenshi: A City Charter is Going to Make Calgary a Better Community,' Oct 7, Calgary Herald. http://calgaryherald.com/opinion/columnists/nenshi-a-city-charter-is-going-to-make-calgary-a-better-community accessed October 13, 2016.

9 Bill Curry, "Canada's Governments Brace for Looming Debt Crunch,” The Globe and Mail, May 12, 2015; and Kyle Hanniman, "Why Municipal Borrowing is No Crisis in Waiting," The Globe and Mail, November 12, 2016.

10

Anthony Sayers, "City Ministers: The Local Politics of Cabinet Selection," in Parties, Elections, and the Future of Canadian Politics, ed. Amanda Bittner and Royce Koop (Vancouver: UBC Press, 2013); Royce Koop and Amanda Bittner, "Parachuted into Parliament: Candidate Nomination, Appointed Candidates, and Legislative Roles in Canada," Journal of Elections, Public Opinion, and Parties 21, 4 (2011): 431-452; Alan Walks, "Suburbanization, the Vote, and Changes in Federal and Provincial Political Representation and Influence Between Inner Cities and Suburbs in Large Canadian Urban Regions, 1945-1999," Urban Affairs Review 39, 4 (2004): 411-440. 
their policy choices, institutions and processes should provide clear lines of authority and transparency of executive action. Clarity of choice and concentration of responsibility are the keys to effective democratic representation. ${ }^{11}$

Figure One models the signalling relationship between voters and governments in the context of the policy process. Voters' preferences are transmitted to government, which in turn responds by generating appropriate policies. At a subsequent election, voters hold government to account by assessing the policy outcomes it has produced. While there are circumstances under which it is possible to construct this as a direct relationship — voters' preferences on an issue are known to the government, which generates a clear policy response that voters directly assess - it is mostly parties and leaders that mediate the relationship via platforms and mandates.

\section{FIGURE ONE A MODEL OF REPRESENTATIVE DEMOCRACY}

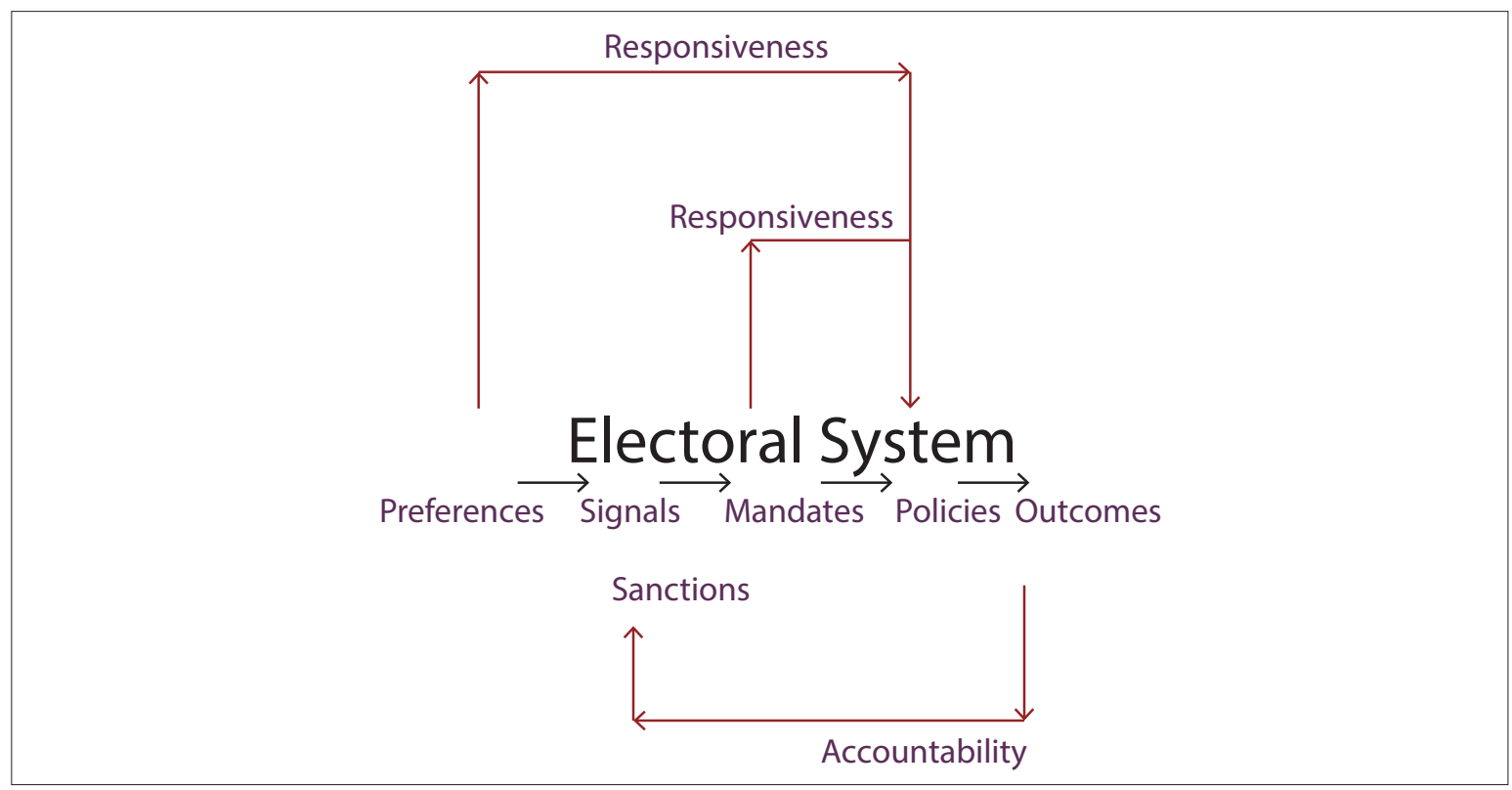

Adapted from Bernard Manin, Adam Przeworski and Susan C. Stokes, "Elections and Representation," in Democracy, Accountability, and Representation, ed. Adam Przeworski, Susan C. Stokes and Bernard Manin (New York: Cambridge University Press, 1999).

Parties and the party system along with the executive are crucial to this view of representative democracy. In competing for office, political parties offer voters suites of policies in the hope of attracting sufficient votes to form or be part of a government. Voters make their choice based on some combination of the candidate and the party platform that best captures their policy preferences.

This arrangement responds to the co-ordination incentives built into electoral systems and legislatures, and by linking candidates to widely advertised party policies it limits the information load voters are required to bear. The more clarity of choice offered to voters clear and stable differences among the candidates for election - the greater the likelihood that their votes will reflect their preferences and that governments will be responsive to these signals. 
Voters use similar cues to limit their informational task in holding governments to account.

For example, they tend to treat government as a single-point actor, assigning responsibility for policies and choices as if an executive had full control of enactment and implementation. ${ }^{12}$ Using this as a guide, they punish or reward the candidates, parties and party leaders linked to the executive. ${ }^{13}$ The greater the concentration of responsibility evident to voters - clear decisions made by identifiable actors - the easier it is for voters to correctly punish or reward politicians for their policy choices. ${ }^{14}$

For their part, governments and politicians are inclined to encourage clear lines of accountability when they perceive it to be to their advantage, and obfuscate lines of accountability when they believe a policy choice might harm their electoral fortunes. This is possible because of the asymmetry between voters, who are information poor, and those they elect, who are not. ${ }^{15}$

Some of the institutional elements associated with clarity of choice and concentration of responsibility, such as parties, party platforms and leaders, are missing in two of our cases and only modestly developed in the third. There are no or only limited party platforms or pronouncements by party leaders that might reduce the effort required of voters to identify where candidates stand or who was responsible for the major decisions of the previous council. The demands on voters wishing to understand policy decisions are great, even if there exist relatively stable voting coalitions. Voters may try to follow the voting behaviour of council members through the media, but this is extremely demanding. The lack of an executive that controls the political agenda removes a major driver of party formation and one of the links in the chain of accountability.

There is however increasing evidence of the role of candidates in shaping voter choice independent of party. In the extreme, voters may use their judgement as to the character of a politician as an algorithm that reduces the information effort required to make a voting choice. On the accountability side, politicians play a key role in making policy outcomes appear consistent with their previous statements and in framing deviations as required by exigent circumstance. ${ }^{16}$ Moreover, there is evidence that civic politicians make choices that are generally consistent with the apparent preferences of voters, although it is difficult to identify the mechanisms that link the two. ${ }^{17}$

12 Christopher Wlezien and Stuart N. Soroka, "Federalism and Public Responsiveness to Policy," Publius: The Journal of Federalism 41, 1 (2011): 31-52.

13 Sara B. Hobolt and James Tilley, Blaming Europe? Responsibility Without Accountability in the European Union (Oxford: Oxford University Press, 2014).

14 Hobolt, Tilley and Banducci, "Clarity."

15 Bernard Manin, Adam Przeworski and Susan C. Stokes, "Elections and Representation," in Democracy, Accountability, and Representation, ed. Adam Przeworski, Susan C. Stokes and Bernard Manin (New York: Cambridge University Press, 1999), 13; John Ferejohn, "Accountability and Authority: Toward a Theory of Political Accountability," in Democracy, Accountability, and Representation ed. Adam Przeworksi, Susan C. Stokes, and Bernard Manin (New York: Cambridge University Press, 1999), 132.

16 James D. Fearon, "Electoral Accountability and the Control of Politicians: Selecting Good Types versus Sanctioning Poor Performance," in Democracy, Accountability, and Representation ed. Adam Przeworski, Susan C. Stokes, and Bernard Manin (New York: Cambridge University Press, 1999).

17 Chris Tausanovitch and Christopher Warshaw, "Representation in Municipal Government," American Political Science Review 108, 3 (2014): 605-641. 
This approach generates a view of the role of candidates in shaping government responsiveness and accountability shown in Table One. Dimension one (vertical) distinguishes between situations of high and low levels of clarity of choice: the extent to which differences among candidates for election are clear and stable over time. Dimension two (horizontal) contrasts high and low levels of concentration of responsibility: the extent to which it is possible to correctly assign responsibility for policy outcomes to candidates.

\section{TABLE ONE CLARITY OF CHOICE AND CONCENTRATION OF RESPONSIBILITY REGIMES}

\begin{tabular}{|c|c|c|c|}
\hline \multicolumn{4}{|c|}{ Concentration of Responsibility } \\
\hline & & High & Low \\
\hline \multirow[t]{2}{*}{ Clarity of Choice } & High & 1 & 2 \\
\hline & Low & 3 & 4 \\
\hline
\end{tabular}

Table One provides us with four archetypal regimes and their associated representatives. We focus on these features at election time, consistent with our data. The top-right and bottom-left corners of the table (types 1 and 4) are the extremes: regimes in which clarity of choice and concentration of responsibility are highly correlated and both are either high or low, with the other two located between these extremes.

In Type 1 regimes, candidate policies are well known and incumbents are strongly associated with major policy decisions, perhaps down to the level where individual votes on major issues are widely known. Clarity of choice and concentration of responsibility are high.

A Type 2 regime operates in an environment where clarity of choice is high but concentration of responsibility is low. Election campaigns accentuate the policy positions of candidates but either due to perhaps turnover or a lack of information, it is difficult to link politicians to government decisions. It may also be that a lack of detailed information leads voters to evaluate the voting record of all councillors equally.

Regimes of Type 3 are characterized by low clarity of choice but high concentration of responsibility. Election campaigns do not focus on the differences between candidates, but do focus on the voting record of the entire council or, in an information-rich environment, individual councillors.

Type 4 is associated with situations of low clarity of choice and low concentration of responsibility. Elections provide nearly no information as to the policy preferences of candidates or past decisions of council. We now move to consider how our data might help us to identify the presence of these regimes at elections in our three case studies.

\section{MEASURING POLITICAL CAREERS}

Our goal is to describe the large-scale, long-term factors that shape accountability and responsiveness in Canadian municipal politics using Calgary, Edmonton and Vancouver. We focus on the development of local political careers as a way of thinking about clarity of choice and concentration of responsibility in a low-information environment that places heavy demands on voters. To this end, we identify four features of civic political careers that might help us to understand the workings of representative democracy at the city level. 
The first is career duration. As Joseph Schlesinger famously noted, the short-term, amateur career - in which men and women briefly take up the noble yoke of office, like Cincinnatus, and then quietly return to private life - may work against responsiveness and accountability. ${ }^{18}$ We are unable to say anything about the conditions under which the councillors in our study were elected (perhaps for example, by pursuing distinctive policies) or whether they were altruistic and sought to represent the interest of their constituents. But it is reasonable to presume that longer careers allow for the possibility of clarity of choice and provide a record on which voters might make judgement in terms of responsibility.

A second relevant consideration is incumbency. Among the key features of municipal politics in Canada, is the remarkable electoral power of incumbents: except in cases of scandal, those who are currently in office are likely to remain if they wish. ${ }^{19}$ While we might legitimately worry about responsiveness and accountability when incumbency rates remain high over extended periods of time, it is possible that they reflect nothing more than ongoing public satisfaction with politicians.

Closely related to incumbency is the question of council turnover. While incumbency rates provide a picture of the likelihood that a politician will be defeated, turnover rates focus on council as a body: the proportion of "new faces" in the council chamber each year. Low turnover rates may improve council's capacity to develop coherent and responsive policies over time and to signal policy positions and outcomes. On the other hand, change may indicate that voters are punishing incumbents for poor performance.

A final consideration is career trajectory. Since Schlesinger's path-breaking work in the 1960s, political scientists have recognized that responsiveness may vary in important ways depending on a politician's career path. Those who harbour ambitions for higher office are likely to look for opportunities to distinguish themselves as innovative policy leaders. ${ }^{20}$ The formal division of authority of Canadian federalism provides opportunities for politicians to signal policy positions and demonstrate a willingness to take responsibility for their actions before running for office at another level. ${ }^{21}$ Our data on political careers allow us to provide an overview of career trajectories and career types over time as indicators of whether politicians make use of these opportunities.

Because we lack a range of information about why politicians chose to run or not run in the elections in our dataset, it is not possible to identify those cases where defeat of incumbents or high rates of turnover are associated with occasions when voters punished politicians for inappropriate or unclear policy positions or what were understood to be poor policy decisions when the politicians were on council. This valuable information awaits resources that would allow researchers to comb archives and newspapers for information on the dynamics of individual elections.

18 Joseph Schlesinger, Ambition and Politics: Political Careers in the United States (Chicago: Rand McNally, 1966).

19 Joseph Kushner, David Siegel and Hannah Stanwick, "Ontario Municipal Elections: Voting Trends and Determinants of Electoral Success in a Canadian Province," Canadian Journal of Political Science 30, 3 (1997): 539-553. Multilevel Systems," Regional and Federal Studies 21, 2 (2011): 117-140; John R. Hibbing, "Legislative Careers: Why and How We Should Study Them," Legislative Studies Quarterly 24, 2 (1999): 149-171; Schlesinger, Ambition.

21 See, for example, Roger B. Myerson, "Local Agency Cost of Political Centralization," discussion paper (University of Chicago, December 2015) http://home.uchicago.edu/ rmyerson/research/localagency.pdf; Doreen Barrie and Roger Gibbins, "Parliamentary Careers in the Canadian Federal State," Canadian Journal of Political Science 22, 1 (1989): 137-145. 
Analyzing careers in this way allows us to better understand the role of local politicians and the character of politics in Edmonton, Calgary and Vancouver. Mapping how clarity of choice and concentration of responsibility are expressed through these careers and how these two factors interact provides a new window into the realities of responsiveness and accountability in Canadian politics

\section{DATA}

We begin with a survey of the long-term landscape: the overall development of municipal careers, council stability and career trajectories of municipal politicians in each of our three case cities over the whole course of their history. This consists of data on the careers of each of the 910 men and women who have been elected to city council in Calgary, Edmonton and Vancouver since each city's incorporation.

The data were compiled using archival sources from each city, to which we then added information on provincial and federal careers using the Canadian Elections Database containing riding-level election results for every provincial and federal election in Canadian history - developed by Anthony Sayers at the University of Calgary. ${ }^{22}$ To our knowledge, these data represent the first large-scale comparative dataset of Canadian municipal political careers ever compiled in Canada, and they provide a useful starting point for our thinking about the nature of responsiveness and accountability at the municipal level.

\section{Career Duration}

We begin with career duration: the length of each mayor or councillor's municipal career in Calgary, Edmonton and Vancouver. Figure Two summarizes overall career lengths in each city from the late 19th century to the present, capturing the average career length of the men and women who sat on council each year. Since many of those who have recently been elected have their careers truncated at the present, each of the figures record a substantial drop in the most recent period; this portion of the figure is best ignored.

22 Sayers, Canadian Elections Database. 

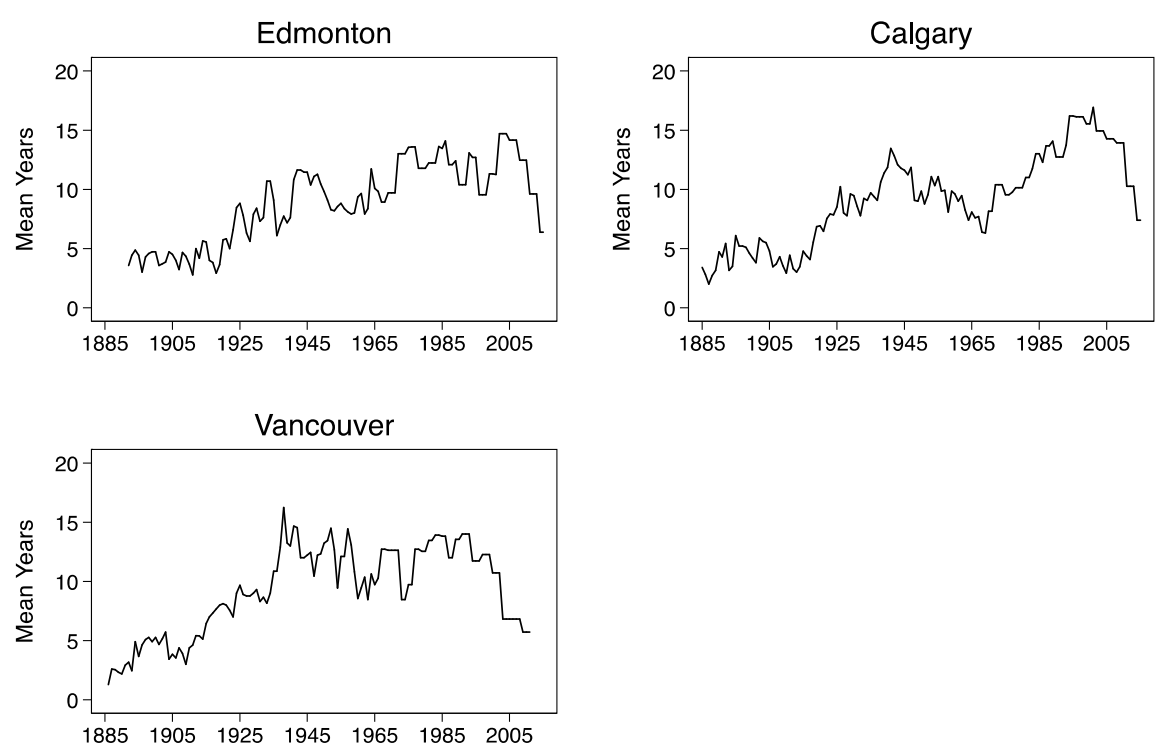

The overall story in each of the three cities is quite clearly one of gradually increasing career lengths. In the late $19^{\text {th }}$ and early 20th centuries, average career lengths were below five years; this increased to about 10 years by the middle of the 20th century, and today average municipal careers are in the 10- to 15-year range in each of the three cities.

Figure Three provides a disaggregated look at each of the 910 careers in the dataset, with Calgary politicians in blue, Edmonton in red, and Vancouver in green. Each circle in the figure represents an individual politician; the horizontal axis captures the year that the politician's career began, and the vertical axis captures the politician's total career length.

FIGURE THREE INDIVIDUAL MUNICIPAL CAREERS IN CALGARY, EDMONTON AND VANCOUVER, BY CAREER LENGTH AND YEAR OF ENTRY (CALGARY IN BLUE, EDMONTON IN RED, VANCOUVER IN GREEN)

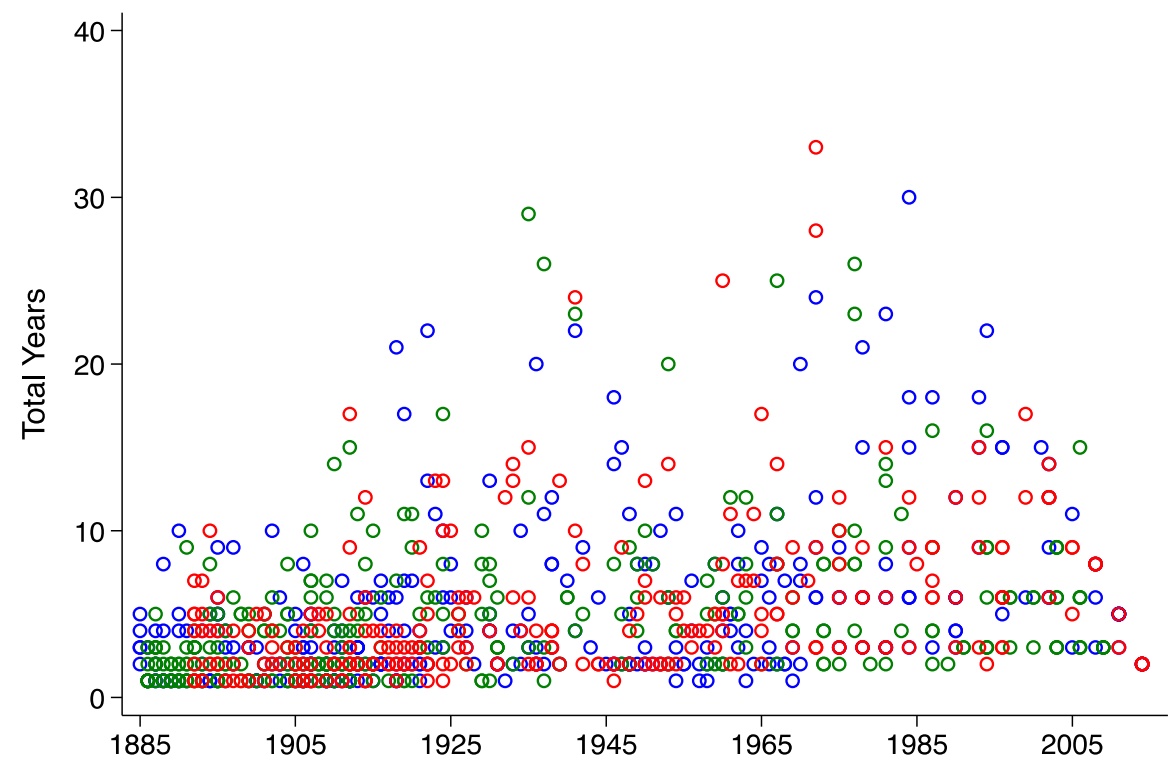


Figure Three allows us to understand three basic realities about municipal careers in our cities. First, the density of circles in the bottom-left area of the figure reveals that political careers of a very short duration were common before the 1930s and remained quite common until the 1960s. After the 1960s, the bottom of the figure begins to "empty out," as very short careers became much less common. Second, the top end of the distribution has also increased over time; careers in the 20-year range appear early in the 20th century, and careers approaching (and then surpassing) 30-year lengths begin to appear in the middle of the 20th century. Third, we can see no obvious patterning in the figure by colour, suggesting that all three cities have had roughly the same distribution of career lengths over time.

\section{Incumbency}

Given that career lengths have increased in Calgary and Edmonton over time, we might assume that incumbent candidates have had more success at re-election in recent years than in the past. But this relationship is not strictly necessary: it may be, for instance, that candidates in the pre-war years retired more frequently than in recent years rather than being more frequently defeated at the polls. We therefore need to examine incumbency rates separately from the question of career lengths and council turnover.

Measuring incumbency rates requires that we have access not only to lists of city councillors and mayors over time, but also to municipal election results. Unfortunately, we have full election results only for the city of Edmonton. Our analysis in this section is therefore based on a separate dataset in which we recorded the number of incumbents who ran for office, and the proportion of those incumbents who were re-elected, for each of the 91 municipal elections in Edmonton's history.

\section{FIGURE FOUR INCUMBENT CANDIDATE SUCCESS IN EDMONTON, BY DECADE}

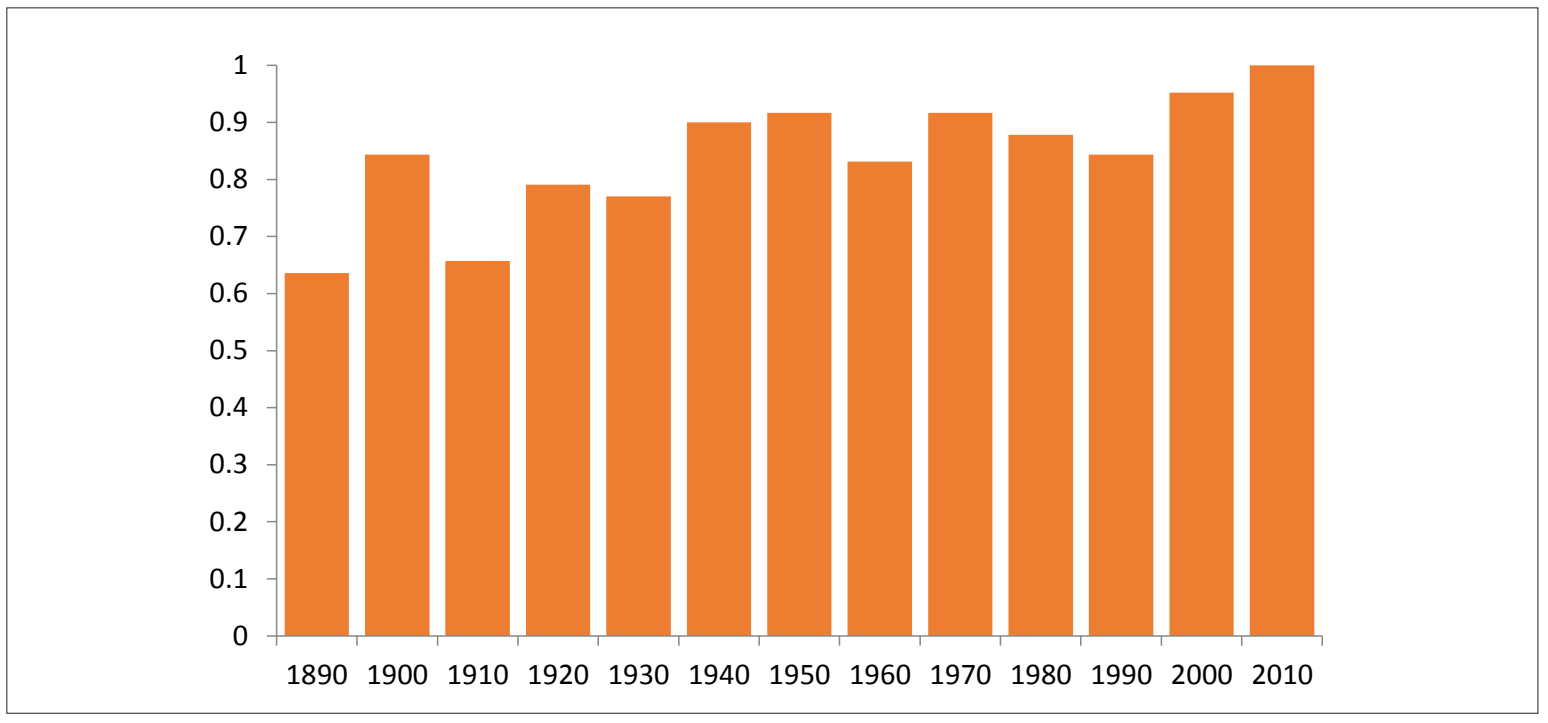

Figure Four reports average incumbency rates for Edmonton municipal elections in each decade from 1890 to 2010. While the decade-by-decade numbers are quite variable, the general trend in the figure is clear, increasing from the 60- to 70-per-cent range in the early period to the 80 -per-cent range in the postwar period. What is most remarkable about the figure, however, is the most recent period. Since 2001 nearly every incumbent in Edmonton 
who has chosen to run for office again in the subsequent election has been re-elected. While these individuals only represent about two-thirds of available municipal positions in the past two decades, it is still very important to recognize the enormous advantage of incumbents in contemporary municipal elections.

\section{Council Stability}

We now turn to council turnover and stability; that is, the proportion of "new faces" on council in any given year. Figure Five provides a year-by-year overview of each city; the grey lines in each figure represent the actual year-by-year stability rate (the proportion of councillors at year $\mathrm{t}+1$ who were also on council at time $\mathrm{t}$ ). In this way, it captures not only the balance of new and returning politicians, but is sensitive to the frequency of elections, or term length.

\section{FIGURE FIVE YEAR-BY-YEAR COUNCIL STABILITY IN CALGARY, EDMONTON AND VANCOUVER}

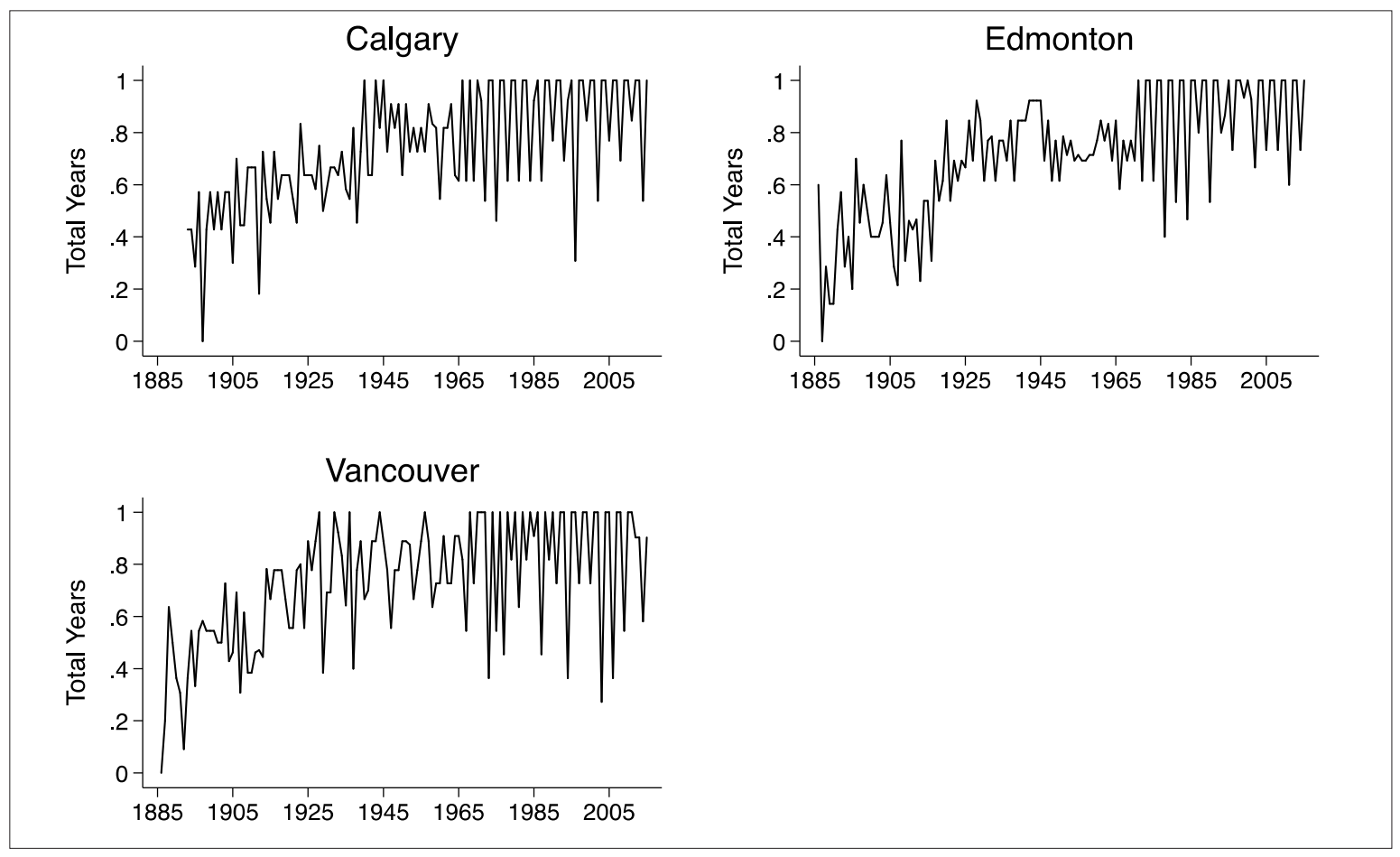

Two features of council stability are obvious in the figure. First is its gradual increase over time: in each of the three cities, year-over-year stability began in the 40-per-cent range in the late 19th century, and has risen into the 80- to 90-per-cent range in recent years. Second is the obvious and unsurprising impact of increased term lengths on stability rates: the increased stability rates clearly reflect the move, first to two-year council terms, in which half of council was up for re-election each year, and then more recently to term lengths for all mayors and councillors of two, three, and ultimately four years. 
FIGURE SIX ELECTION-BY-ELECTION STABILITY RATES IN CALGARY, EDMONTON AND VANCOUVER

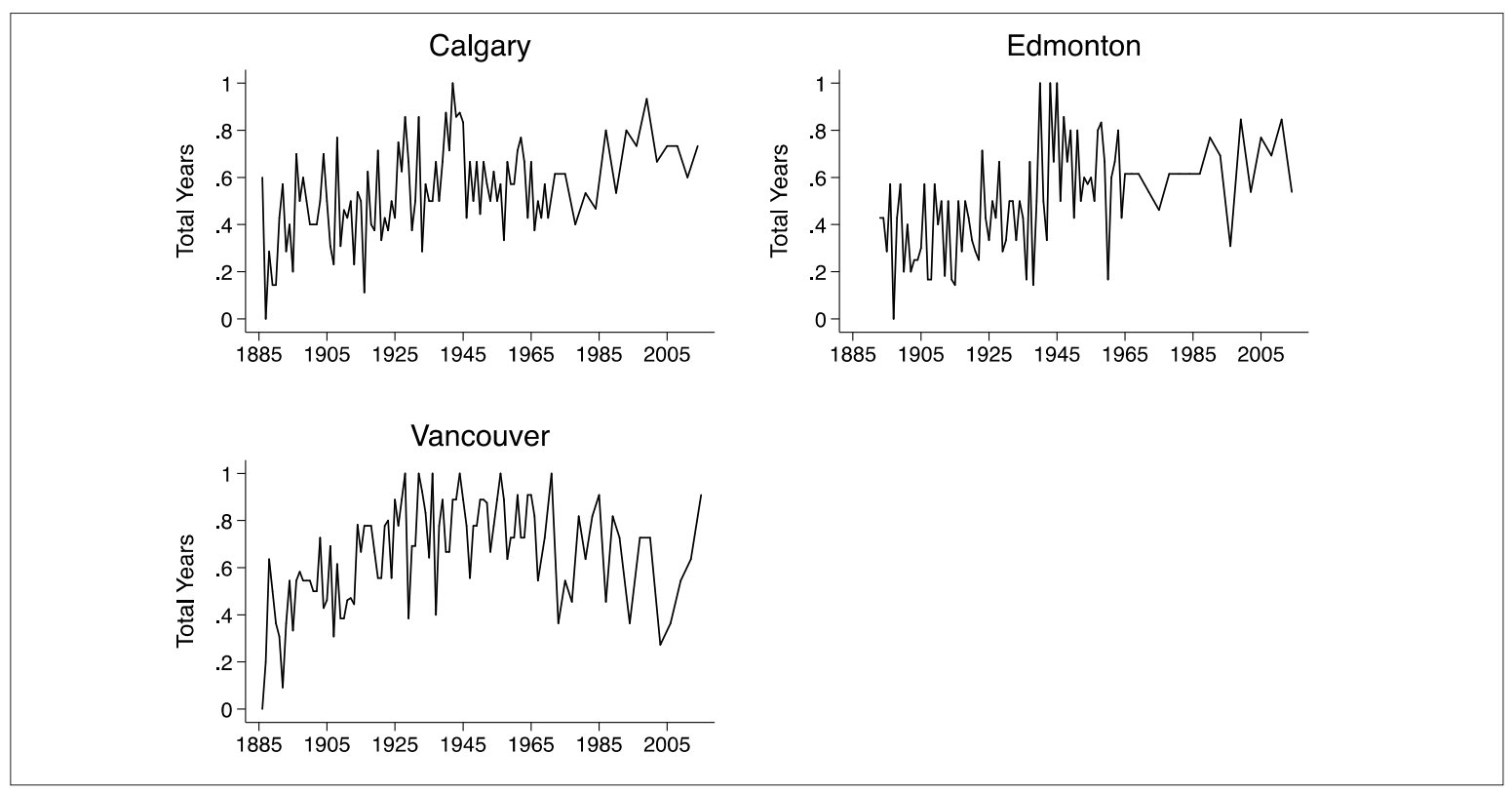

Because of the powerful impact of term lengths on the year-by-year figures, it is also useful to look at election-by-election stability rates in each city. These stability rates are pictured in Figure Six. In Calgary and Edmonton, the figures appear to be roughly similar: somewhat lower stability in the very early years, very high stability in the middle of the 20th century (driven in large part by the fact that municipal elections in both cities were uncompetitive, and in some cases simply uncontested, during the Second World War), and then stability rates in the 60- to 70-per-cent range during the postwar era.

Vancouver's election-by-election stability rates appear to tell a somewhat different story: one of gradual increase up to the middle of the 20th century, followed by an overall decline in stability rates since the end of the Second World War. This difference may be due to the persistence of municipal political parties in Vancouver elections during the same period (the 1960s to 1980s) when such parties were fading into obscurity in Calgary and Edmonton. This partisan persistence in Vancouver may be the result of institutional differences - Calgary and Edmonton abandoned at-large voting in 1961 and 1971, while the at-large system persists in Vancouver up to the present - or it may reflect deeper differences in political competition in the two cities. These possibilities are well worth future investigation.

\section{Career Trajectory}

Do municipal politicians also serve at the provincial or federal level in Canada? To answer this question, we have searched the Canadian Elections Database for each of the 910 municipal politicians in the dataset. Table Two provides an overview of our findings. Overall, levels of provincial participation appear to be somewhat higher in Alberta cities (just over 10 per cent in both cases) than in Vancouver, where only five per cent of Vancouver politicians have also been elected provincially. At the federal level, the numbers 
are low in all three cities: just 22 of the 910 municipal politicians in Calgary, Edmonton and Vancouver have also been elected to the federal Parliament. ${ }^{23}$

TABLE TWO THE PROVINCIAL AND FEDERAL CAREERS OF CIVIC POLITICIANS

\begin{tabular}{|c|c|c|}
\hline & Provincial & Federal \\
\hline Calgary & $36 / 340(11 \%)$ & $6 / 340(2 \%)$ \\
\hline Edmonton & $31 / 264(12 \%)$ & $11 / 264(4 \%)$ \\
\hline Vancouver & $16 / 306(5 \%)$ & $5 / 306(2 \%)$ \\
\hline Total & $83 / 910(9 \%)$ & $22 / 910(2 \%)$ \\
\hline
\end{tabular}

Our data also allow us to summarize the order in which politicians move through the different offices. Table Three below provides a summary of all careers in the dataset involving one or two career stages; interestingly, this represents more than 98 per cent of all the careers in the dataset, demonstrating that multi-stage political careers (such as municipal-provincial-federal), common in the United States, are very rare in Canada. As mentioned above, the overwhelming majority of politicians in each city have municipalonly careers. Of those who do have provincial or federal experience, however, the most common career trajectory is to move from the municipal to the provincial level. Of those municipal politicians who also have provincial or federal political experience, the overwhelming majority begin their careers in municipal politics before entering the provincial or federal arenas.

TABLE THREE THE CAREER TRAJECTORIES OF CIVIC POLITICIANS

\begin{tabular}{|c|c|c|c|c|c|}
\hline Stage 1 & Stage 2 & Calgary & Edmonton & Vancouver \\
\hline Municipal & & $88 \%$ & $85 \%$ & $93 \%$ & $3 \%$ \\
\hline Municipal & Provincial & $8 \%$ & $9 \%$ & $3 \%$ & $1 \%$ \\
\hline Municipal & Federal & $1 \%$ & $2 \%$ & $1 \%$ & $1 \%$ \\
\hline Provincial & Municipal & $0.6 \%$ & $1 \%$ & $0.3 \%$ \\
\hline Federal & Municipal & $0.3 \%$ & $0.4 \%$ \\
\hline
\end{tabular}

\section{DISCUSSION}

Using the data to map municipal politicians onto our four-way typology of clarity of responsiveness and concentration of responsibility allows us to consider the character of representative politics in Calgary, Edmonton and Vancouver. The general impression is of growing overall predictability in the character of representation in the three cities. The current average career length of 10 to 15 years is essentially three times what it was in the late 19th century. We can be sure that this reflects high rates of incumbency in Edmonton, for which we have data, but without detailed electoral data from the other cities, we are unable to say for sure if this is true for these cases. Even in Edmonton, it is not easy to say much more without detailed knowledge of why individual incumbents won or lost. A scan of reports on recent elections suggests Calgary currently experiences very high levels of incumbency, while rates in Vancouver are somewhat lower but still in the 80-per-cent range.

3 Because our focus is on political careers, we focus on those who have been elected at the provincial and/or federal levels, rather than those who have run for office at those levels and lost. We manually searched the Canadian Elections Database for first and last names. In some cases names were similar but not identical, or candidates were in the database from other cities, requiring us to undertake additional biographical research to confirm that the person was indeed a match. 
Stability is a cruder measure than incumbency, as it treats politicians who choose to retire rather than contest and possibly lose an election in the same way as those who are defeated. Yet even stability is remarkably high. In recent times in Calgary and Edmonton, around 80 to 90 per cent of councillors can be found back on council following an election, double the proportion for the earliest period. The pattern is less clear for Vancouver, but it too experiences much more stability than in earlier elections, with 60 to 80 per cent of councillors regularly returning to council.

The Vancouver experience of somewhat lower levels of stability than either Calgary or Edmonton alerts us to the possibility that the presence of political parties, absent in the other cities in recent years, might play a role in shaping the predictability of election outcomes in the West Coast city. This greater role for parties in Vancouver may result from the continued use of a single, citywide electoral district, which strengthens the gains to candidates from co-ordinated campaigns. Calgary and Edmonton also had organized parties in periods when elections were in a single, at-large electoral district. ${ }^{24}$ A single electoral district might lower the informational load on voters in both selecting (responsiveness) and rewarding or punishing (accountability) politicians for their policy positions and decisions, the mirror effect of the advantages to politicians of sharing the cost of campaigning by forming parties in these types of contests.

The observed most common career paths, from municipal to provincial and to a lesser degree federal politics, are consistent with the theorized relationship: politicians use both the experience and exposure of municipal politics to build the skills and name recognition for success at elections with broader electorates. Associated with this is greater voter awareness of both the political positions (responsiveness) and performance (accountability) of these politicians. The numbers are small, suggesting that municipal politics is not seen as a required training ground for future provincial or federal politicians, with Alberta politicians much more likely to find this career path appealing than their British Columbian counterparts. However, the system as a whole benefits from the theorized advantages in terms of responsiveness and accountability that come with this type of political career.

\section{Local Careers and Responsiveness and Accountability Regimes}

Our four ideal types of responsiveness and accountability regimes are helpful as a heuristic to guide our analysis of representation at municipal elections in Calgary, Edmonton and Vancouver. They sensitize us to what might be the causes of the identified stability. Either voters are very happy with their municipal politicians or they are lack some information that might lead them to vote against incumbents. Unfortunately, we do not have sufficient data on civic elections over time with which to assess this claim, such as the major issues, positions of councillors, and importance of the previous decisions of council. As such, our comments are of a general nature.

Given the lack of turnover, it is unlikely that our three cases currently experience Type 4 elections. ${ }^{25}$ We know relevant information is in general more difficult to come by than

\footnotetext{
Jack Masson and Edward C. LeSage Jr., Alberta's Local Governments: Politics and Democracy (Edmonton, Alta.: University of Alberta Press, 1994).

25 A reminder: in terms of clarity and responsibility respectively, Type 4 is low-low, Type 3 is low-high, Type 2 is high-low and Type 1 is high-high.
} 
at provincial or federal elections. Yet the fact that many candidates have repeatedly run for and won office should provide voters with information on the policy position of those seeking re-election. One would think this might also allow challengers the possibility of running against the well-known position of an incumbent, clarifying choice, but this is dependent on sufficient coverage and interest. Voters should also be able to assign responsibility for past decisions to any of the long-serving members of council, although they may not be able to distinguish among them. On this basis, recent elections in Calgary, Edmonton and Vancouver are not low-clarity, low-responsibility affairs.

Type 3 dynamics do not seem to capture recent elections in our case studies. Stability of choice suggests that voters are likely to have some idea of where councillors stand on major issues. The degree to which the high threshold for responsibility implied by this election type is met depends on how we judge accountability. If we accept that voters apply their view of council equally to all incumbents, the threshold may well be met. All that is required is a general sense of whether council has behaved appropriately. We cannot say whether voters make use of individual voting records, a much higher bar, in choosing a candidate. Given evidence from elsewhere that when there is turnover councillors tend to be swept away as a group, ${ }^{26}$ the first scenario seems more likely and might be considered as meeting the requirement of Type 3 elections.

Type 2 has some appeal as a description of elections in our three cities. Clarity of position should be high given that most politicians have been in office for some time. But this model is not descriptive if we take responsibility to be of the collective sort noted above. Collective responsibility would exceed the low threshold required by this model. Requiring evidence of the use of individual voting records would be a tougher test, although as the bar is set low, even this might be met.

It seems that Type 1 is descriptive of clarity of choice in our case studies if we accept that stability provides sufficient information for voters to understand the policy positions of incumbents. We cannot know without further study whether coverage of civic elections reaches this threshold, or if voters are paying attention. If we accept that voters might assign their general sense of council votes - that is, whether they are in the broad policy direction they favour or not - to all incumbents equally, then concentration of responsibility would operate. If the question is, rather, can they assign responsibility at an individual level on the basis of votes on council, it is unclear whether this threshold is met.

In general, to the degree that stability allows voters to identify the policy positions of incumbent councillors and assign responsibility for past actions, this should favour greater clarity of responsiveness (the vertical scale) and concentration of responsibility when applied to incumbents as a group (the horizontal scale). The career trajectories for those who move beyond municipal politics would have a similar effect. Without detailed attitudinal and knowledge surveys of municipal voters, it is very difficult to be more precise.

\footnotetext{
Andrew Sancton, "What happened to incumbent councilors in Greater Sudbury and London, Ontario in 2014? The Role of the Ontario Ombudsman's Reports on Secret Meetings," unpublished manuscript.
} 


\section{Careers, Incumbency and Democracy}

Our city-election case studies present an interesting challenge for democratic theory. Responsiveness and accountability, understood as clarity of choice and concentration of responsibility, are likely to improve with longer careers, greater incumbency and stability, and the movement of individual councillors to other levels of government. The longer a politician is around, the more likely it is that voters are aware of her or his policy positions and decisions. This finding is perhaps most surprising with respect to accountability. Stability is the antithesis of our general sense that the defeat of incumbents who have failed in some way is the gold standard for retrospective or economic voting.

Despite the sense that re-election or defeat are tests of responsiveness or accountability voting, this is open to interpretation. Re-election does not necessarily mean acceptance of policy promises or reward, but may reflect inertia or perhaps limited support shaped by the availability of information, the alternatives confronting voters, and the differing roles of representatives. ${ }^{27}$ Even defeat, which might be more easily read as rejection of policy or as punishment, could be capturing a range of other personal or partisan considerations and changes in the choice of candidates offered to voters. The character of both responsiveness and accountability are inextricably linked to contingent factors and institutional logics and incentives that vary by time and place. ${ }^{28}$

It may be that our models of responsiveness and accountability need serious renovation. There is growing evidence that voters do not seem much engaged in politics nor well informed. Rather than careful assessment of long-term government performance, recent events heavily influence their vote. Group rather than individual identities may play a key role in shaping perceptions of politics and preferences. It also seems that voters are inclined to align their preferences with those of the parties, candidates, and leaders they prefer rather than their own self-interest. ${ }^{29}$ By this account, voting is not about signalling individual policy preferences and assessing government actions so much as choosing an appealing candidate based on short-term, group-based preferences. The peculiar dynamics of civic politics provide us with an opportunity to reconsider the character of responsiveness and accountability and the role of political parties shown in Figure One.

\section{The Struggle for Parties in Civic Politics}

Political party formation is a response by politicians to the intractable co-ordination issues that plague mass politics. They are co-ordination mechanisms for solving the collectiveaction challenges of organizing and articulating interests and solving social-choice problems associated with legislating policy outcomes. Parties operate within a political and institutional context that defines incentives that in turn shape the behaviour of politicians in their search to gain and hold office. They fill a gap, offering solutions to problems that

\footnotetext{
Heinz Eulau and Paul D. Karp, “The Puzzle of Representation: Specifying Components of Responsiveness," Legislative Studies Quarterly 2, 3 (1977): 233-254. 
current institutional arrangements do not solve directly and that politicians have come to believe cannot be solved in any other way. ${ }^{30}$

Political parties do not exist in two of our three cases, and in the one case where they do exist they may offer only limited assistance in helping voters clarify their choices or understand who is responsible for previous government decisions. Compared to provincial or federal elections, the parties' policy platforms are not strongly developed, their campaigns are not high-spending nor high-contact affairs, and the cohesiveness of those running under party banners is highly variable. ${ }^{31}$ There is evidence that electoral systems help shape these differences. Single citywide electorates may favour the formation of parties, perhaps because they help candidates solve a severe electoral co-ordination problem, lowering the cost of campaigning. Their legislative role may be vestigial.

Civic politicians appear to have identified alternative means for solving the collectiveaction and social-choice problems associated with elections and governing. If there are no unsolved problems that the additional co-ordination offered by parties might address, there is no need for them. There may be other barriers to their success, but we would need more information than is currently available, perhaps from interviews with politicians, to say much about these. Our study helps us to think about how municipal politicians might balance the advantages that come with the electoral and legislative co-ordination offered by parties against the compromises they entail.

Sharing the costs of elections, particularly where a ward system is in use, may be of little consequence in what are generally low-competition and modest-spending affairs. Incumbent councillors should have the wherewithal to run competent candidate-centred campaigns. The aggregating and articulation of interests that come from electoral coordination may have limited appeal. As independent agents, they may more easily avoid policy positions that hurt their chances of re-election. Absent a first mover, there may be not much advantage to party formation. Policy flexibility may favour electoral success.

The lack of parties may also be helpful in allowing civic politicians to blur distinctions between themselves, their council colleagues, or electoral opponents. They remain free to build an individual policy profile - emphasizing issues that favour them — or blur distinctions between them and other members of council or electoral challengers. From this perspective, political parties deliver only the costs of co-ordination to politicians. Any additional clarity of choice and/or concentration of responsibility that parties deliver is best avoided if, together with the other costs parties impose, councillors see them as reducing their chances of re-election.

Agenda control is central to the power of executives in most parliamentary systems and underpins the development of disciplined parties. ${ }^{32}$ Mayors in our three cities do not dominate the legislative agenda and are unable to enforce voting outcomes. ${ }^{33}$ They do

\footnotetext{
30 John Aldrich, Why Parties? The Origin and Transformation of Political Parties in America (Chicago: University of Chicago Press, 1995).

31 Paul Tennant, "Vancouver Civic Politics, 1929-1980," BC Studies 46 (1980): 3-27; C. Richard Tindal et al., Local Government in Canada (Toronto: Nelson Education, 2017).

32 Cox, The Efficient.

33 Richard D. McKelvey, "Intransitivities in Multidimensional voting Models and Some Implications for Agenda Control," Journal of Economic Theory 12 (1976): 472-482.
} 
not possess the power to create rules and administrative procedures to reward or punish councillors for how they vote. If little is to be gained from dominating the office, a major impulse for legislative co-ordination is absent, as are its indirect co-ordinating effects.

Lack of agenda control may be another reason why councillors might not wish to oversell their voting records. Not only is no one in control, but voters may well misunderstand the limited power of the mayor, assigning too much responsibility for council decisions to the office and perhaps to those councillors who voters believe are aligned with the mayor. Party membership looks unappealing from this perspective as well. The freedom to shape an image of their policy performance with little media oversight is likely a net win for councillors. General claims about "wanting what is good for the city" may go uncontested. It is not trivial that by advertising events in parliament, the English media played a key role in strengthening the role of parties and concentrating the power of the executive in $19^{\text {th }}$ century Britain. ${ }^{34}$ The disaggregated nature of Canadian parties and federal and provincial party systems may also reduce external pressure for electoral or policy co-ordination. ${ }^{35}$

With little to hold legislative coalitions together, it is more likely that they will form and dissolve by issue. Once patterned, this behaviour may satisfy politicians. Incumbents might wish to limit evidence of patterned policy agreement or disagreement as a collective response to electoral challengers. This is particularly true for ward-based elections, as incumbent councillors do not normally compete against each other. If city councillors inhabit what they think of as an optimum position with respect to their chances of reelection, any change threatens greater uncertainty. They may well prefer a low-information environment with limited competition, no parties and great electoral stability.

For voters, seeing little change at elections, noting that this has generated few crises, and knowing relatively little about councillors (or, put differently, facing a heavy burden to understand their policy positions), they may be inclined to either re-endorse politicians who have avoided scandal, or perhaps not vote at all. Voters are likely to choose councillors based on experience. That can only be to the advantage of incumbents, the exception being those rare cases where the whole of council falls into disrepute.

Instead of hoping to hold civic politicians accountable for their policy positions or actions, voters may be choosing to vote for what they perceive to be a trustworthy, "good type" of politician who has experience on a council that has had few scandals. This is a useful shortcut or algorithm for voters operating in a low-information environment who do not wish to expend the effort required to make a more nuanced decision. ${ }^{36}$ This reinforcing set of ideas is consistent with much of what we know about civic elections, and may help explain why much of the infrastructure normally associated with responsiveness and accountability seen in Figure One is missing. Exploring these questions is beyond the scope of this study, but clearly deserving of future attention.

34 Cox, The Efficient, 53-60.

35 David Stewart, Anthony M. Sayers and R. Kenneth Carty, "Partisan Competition in the Canadian Prairies," in Provinces: Canadian Provincial Politics, ed. Christopher Dunn (Toronto: University of Toronto Press, 2015).

36 Fearon, "Electoral." 


\section{CONCLUSION}

The responsiveness of politicians to voters and the accountability of officeholders for past decisions are central to representative politics. In the absence of information (such as voter surveys tied to our cases) exploring whether voters can identify the positions of individual councillors and align them with their own, we must be cautious. Similarly, without knowing why some politicians lose, it is not clear whether success or failure depends upon voters holding them to account by rewarding or punishing them for their policy decisions.

We use patterns of career length, incumbency, council stability and career trajectory of politicians in Calgary, Edmonton and Vancouver to begin exploring how responsiveness and accountability, understood as clarity of choice and concentration of responsibility, operate at civic elections. We find that the signalling mechanisms associated with each do not operate in the same way as they do in other forms of elected politics. Stability, rather than competition, provides the major route for information to flow to voters about the policy positions and prior decisions of civic politicians.

The politics of these councils is very different from that of parliamentary governments and their election contests. Many of the mechanisms associated with responsiveness and accountability on display in Figure One are missing or of limited strength in our three cities. Political parties are weak or non-existent, while executive control of the legislative agenda is limited. Given increasing skepticism as to the role political parties play in signalling individual voter preferences at election, these cases offer an opportunity to rethink our concepts of modern democratic representation.

We know that civic elections are low-information environments and that this may complicate the task of clarifying policy responsiveness and accountability among those seeking office. Our data show that civic politicians do not suffer the regular defeat that might suggest they are being held responsible for their policy choices while in office. This is slightly less true in Vancouver, where we have noted that the presence of political parties may play a role in allowing for this sort of signalling. But it is also true that high levels of stability do not in themselves indicate a failure of these mechanisms.

To the degree that stability lowers the informational requirement on voters with respect to knowing the policy position of councillors and how they have voted on council, it may well improve clarity of choice and concentration of responsibility. It may also be that stability, low information, and low voter turnout are self-reinforcing. With little knowledge of councillors or their actions, a presumption that little will change, and evidence that this has in general led to acceptable political outcomes, voters may well feel little is to be gained from removing incumbents or even voting in the first place.

We suggest as an initial hypothesis that the incentive structures facing councillors in wardbased elections do not favour party formation, and that this may reveal that it is in the interests of civic politicians to sustain a low-information environment. This is captured in Figure Seven. Routes 2 and 3 describe the process voters follow to vote for a policy preference or hold politicians accountable for past decisions. By encouraging voters to travel route 1 , civic politicians reduce information collection by voters and encourage competition on non-policy matters such as personal characteristic, including experience on council. 


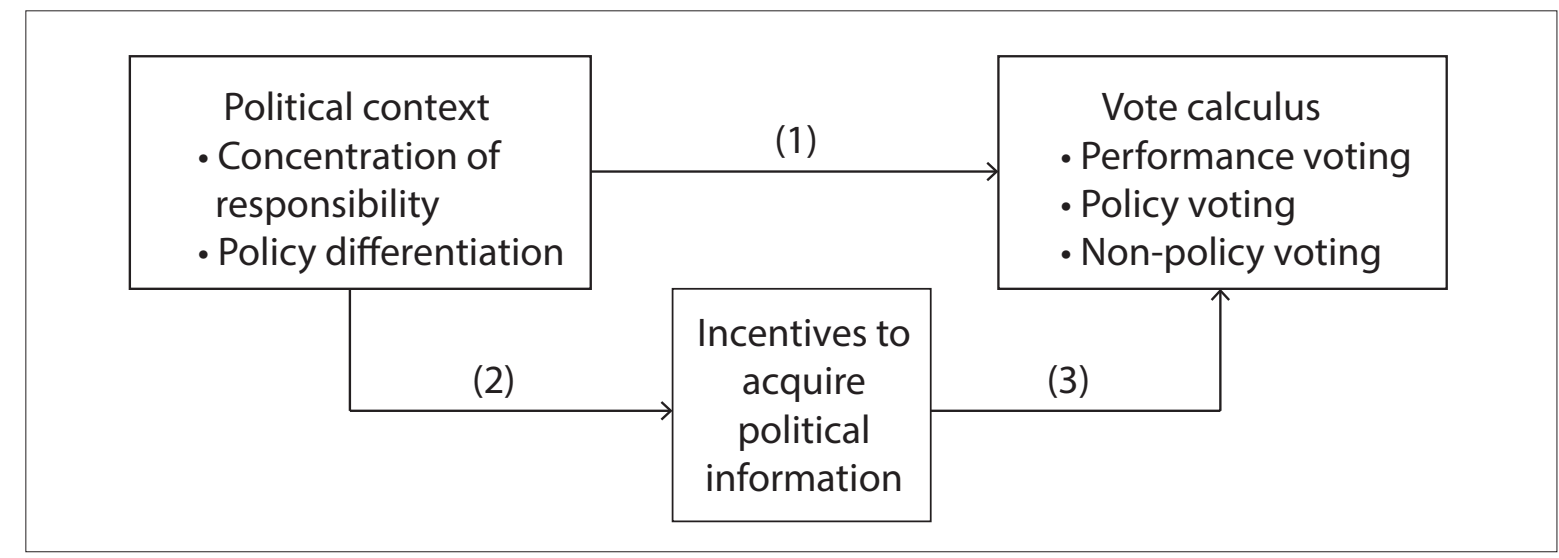

Hellwig, Timothy. 2011. 'Context, Political Information, and Performance Voting,' in Russell J. Dalton and Christopher Anderson (Eds.), Citizens, Context, and Choice: How Context Shapes Citizens' Electoral Choices, New York NY.: Oxford University Press.

In this stable, low-information environment, councillors may be willing to satisfice in terms of policy outcomes as a means of avoiding the higher transaction costs associated with competitive elections. ${ }^{37}$ Under these conditions, councils are likely to act as corporate bodies rather than expressing the predictable divisions associated with more partisan legislatures.

In other words, when given a choice between the uncertainty and extra demands of an information-rich, highly competitive electoral and legislative domain and that of a potentially more controllable low-information, modestly competitive environment, civic politicians favour the second. They limit policy differences and seek out the support of repeat voters who cast their vote based on experience on council. Exploring this question is beyond our present study, but one we think worthy of attention.

Those wishing to engage our city councils in policy discussion should be aware of these unusual dynamics. Stability and unity suggest that long-term strategies of persuasion and an emphasis on common purpose - seeking consensus - may well be more effective than short-run attempts to dominate or divide council. Internal coalitions, where they do exist, are likely to be too unstable to provide a basis for long-term strategic behaviour.

As well, the lack of an executive with clear agenda control is both a challenge and an opportunity. While it complicates the task of shaping legislative outcomes, it may limit the capacity of council to fully exclude issues raised by external pressure. Together with the consensual nature of decision-making, this may contribute to policy inertia, suggesting that successes may be difficult to overturn.

Finally, councillors may see attempts to divide them or unseat their compatriots at election time as reducing their own chances of re-election, and therefore as personal attacks and a threat to their collective existence. At the same time, the rare open elections that result from retirements offer opportunities for reshaping - if only somewhat - the policy composition of council through engagement in the electoral process.

\footnotetext{
7 James G. March and Herbert Simon, Organizations, (New York: Free Press, 1958); Ronald Coase, "The Nature of the Firm," Economica, 4 (1937): 386-405.
} 


\title{
ABOUT THE SCHOOL OF PUBLIC POLICY
}

The School of Public Policy has become the flagship school of its kind in Canada by providing a practical, global and focused perspective on public policy analysis and practice in areas of energy and environmental policy, international policy and economic and social policy that is unique in Canada.

The mission of The School of Public Policy is to strengthen Canada's public service, institutions and economic performance for the betterment of our families, communities and country. We do this by:

- Building capacity in Government through the formal training of public servants in degree and non-degree programs, giving the people charged with making public policy work for Canada the hands-on expertise to represent our vital interests both here and abroad;

- Improving Public Policy Discourse outside Government through executive and strategic assessment programs, building a stronger understanding of what makes public policy work for those outside of the public sector and helps everyday Canadians make informed decisions on the politics that will shape their futures;

- Providing a Global Perspective on Public Policy Research through international collaborations, education, and community outreach programs, bringing global best practices to bear on Canadian public policy, resulting in decisions that benefit all people for the long term, not a few people for the short term.

Our research is conducted to the highest standards of scholarship and objectivity. The decision to pursue research is made by a Research Committee chaired by the Research Director and made up of Area and Program Directors. All research is subject to blind peer-review and the final decision whether or not to publish is made by an independent Director.

\author{
The School of Public Policy \\ University of Calgary, Downtown Campus \\ 906 8th Avenue S.W., 5th Floor \\ Calgary, Alberta T2P $1 \mathrm{H} 9$ \\ Phone: 4032103802
}

\section{DISTRIBUTION}

Our publications are available online at www.policyschool.ca.

\section{DISCLAIMER}

The opinions expressed in these publications are the authors' alone and therefore do not necessarily reflect the opinions of the supporters, staff, or boards of The School of Public Policy.

\section{COPYRIGHT}

Copyright (C) 2017 by The School of Public Policy.

All rights reserved. No part of this publication may be reproduced in any manner whatsoever without written permission except in the case of brief passages quoted in critical articles and reviews.

\section{DATE OF ISSUE \\ March 2017}

\section{MEDIA INQUIRIES AND INFORMATION}

For media inquiries, please contact Morten Paulsen at 403-220-2540. Our web site, www.policyschool.ca, contains more information about The School's events, publications, and staff.

\section{DEVELOPMENT}

For information about contributing to The School of Public Policy, please contact Paul Beaudry by telephone at 403-220-4624 or by e-mail at paul.beaudry1@ucalgary.ca.

\section{ISSN}

1919-112x SPP Research Papers (Print)

1919-1138 SPP Research Papers (Online) 


\title{
RECENT PUBLICATIONS BY THE SCHOOL OF PUBLIC POLICY
}

\author{
80,000 INACTIVE OIL WELLS: A BLESSING OR A CURSE? \\ http://www.policyschool.ca/wp-content/uploads/2017/02/Inactive-Oil-Wells-Muehlenbachs-1.pdf \\ Lucija Muehlenbachs | February 2017
}

DISCERNING 'FUNCTIONAL AND ABSOLUTE ZERO': DEFINING AND MEASURING AN END TO HOMELESSNESS IN CANADA

http://www.policyschool.ca/wp-content/uploads/2017/01/Absolute-Zero-Turner-Albanese-Pakeman.pdf

Alina Turner, Tom Albanese and Kyle Pakeman | January 2017

\section{PUBLIC-INTEREST BENEFIT EVALUATION OF PARTIAL-UPGRADING TECHNOLOGY}

http://www.policyschool.ca/wp-content/uploads/2017/01/PIB-Evaluation-Fellows-Mansell-Schlenker-Winter.pdf

G. Kent Fellows, Robert Mansell, Ronald Schlenker and Jennifer Winter | January 2017

MUNICIPAL REVENUE GENERATION AND SPRAWL: IMPLICATIONS FOR THE CALGARY AND EDMONTON METROPOLITAN REGIONS DERIVED FROM AN EXTENSION OF "CAUSES OF SPRAWL" (TECHNICAL PAPER)

http://www.policyschool.ca/wp-content/uploads/2016/12/MRG-Technical-Paper-McMillan.pdf

Melville McMillan | December 2016

MUNICIPAL REVENUE GENERATION AND DEVELOPMENT IN THE CALGARY AND EDMONTON METROPOLITAN REGIONS

http://www.policyschool.ca/wp-content/uploads/2016/12/MRG-Development-Conger-Dahlby-McMillan.pdf

Brian Conger, Bev Dahlby and Melville McMillan | December 2016

THE CORPORATE INCOME TAX IN CANADA: DOES ITS PAST FORETELL ITS FUTURE? 2015 TAX-COMPETITIVENESS REPORT: CANADA IS LOSING ITS ATTRACTIVENESS

http://www.policyschool.ca/wp-content/uploads/2016/12/Corporate-Income-Tax-Bird-Wilson.pdf Richard Bird and Thomas Wilson | December 2016

http://www.policyschool.ca/wp-content/uploads/2016/11/Tax-Competitiveness-Bazel-Mintz.pdf Philip Bazel and Jack Mintz | November 2016

IF IT MATTERS, MEASURE IT: UNPACKING DIVERSIFICATION IN CANADA

http://www.policyschool.ca/wp-content/uploads/2016/11/Diversification-in-Canada-Tombe-Mansell.pdf Trevor Tombe and Robert Mansell | November 2016

ALBERTA'S NEW ROYALTY REGIME IS A STEP TOWARDS COMPETITIVENESS: A 2016 UPDATE

http://www.policyschool.ca/wp-content/uploads/2016/10/AB-New-Royalty-Regime-Crisan-Mintz-final.pdf Daria Crisan and Jack Mintz | October 2016

A RULE OF REASON FOR INWARD FDI: INTEGRATING CANADIAN FOREIGN INVESTMENT REVIEW AND COMPETITION POLICY http://www.policyschool.ca/wp-content/uploads/2016/10/Foreign-Investment-Bishop-Final.pdf Grant Bishop | October 2016

FROM IMPACT ASSESSMENT TO THE POLICY CYCLE: DRAWING LESSONS FROM THE EU'S BETTER-REGULATION AGENDA

http://www.policyschool.ca/wp-content/uploads/2016/10/Financial-Regulation-Renda.pdf Andrea Renda | October 2016

GETTING FINANCIAL REGULATIONS RIGHT: AVOIDING UNINTENDED EFFECTS

http://www.policyschool.ca/wp-content/uploads/2016/10/Financial-Regulations-Coolidge-Mintz.pdf Jacqueline Coolidge and Jack Mintz | October 2016 